Vol 6 No 1 February 2021

ORIGINAL ARTICLE

\title{
Comparison of the Incidence of Nausea and Vomiting in the Administration of Tramadol 100 mg Suppositories with Intravenous Post-Spinal Anesthesia for Lower Extremity Surgery
}

\author{
Adhi Setia Putra \\ Department of Anesthesia and Reanimation, Faculty of Medicine, University of Sumatera Utara \\ Correspondence email: $\underline{\text { dradhisetiaputra@gmail.com }}$
}

\begin{abstract}
Postoperative nausea vomiting (PONV) after intravenous administration of tramadol has a high incidence rate, so it needs alternative drug administration to overcome this problem. This study aims to compare the incidence of postoperative nausea and vomiting in the intravenous administration of tramadol suppositories. A double-blind analytical experimental study, involving 36 subjects divided into tramadol suppositories and intravenous tramadol postextremity surgery with spinal anesthesia at Haji Adam Malik Hospital and Network Hospital in 2013. The incidence of PONV in tramadol suppository subjects was much lower than in intravenous tramadol subjects.
\end{abstract}

Keywords: tramadol, suppository, PONV

\section{INTRODUCTION}

One of the complications that often occur within 24 hours postoperatively is nausea and vomiting, known as postoperative nausea vomiting (PONV) with an incidence of up to $30 \%$ to $40 \%$. PONV occurs due to the administration of pain relievers that act on the central nervous system to manage postoperative pain. ${ }^{1}$

One of the most commonly used pain relievers is Tramadol, an opiate analgesic that inhibits serotonin $(5 \mathrm{HT} 3)$ reuptake in the central nervous system. Tramadol has the undesirable effect of stimulating the vomiting center by the chemoreceptor trigger zone (CTZ) in the brain due to the large amount of serotonin that fails to dissolve. $^{2}$
Various attempts to minimize the side effects of Tramadol administration have been carried out through variations in drug administration and by a combination of nonopiate analgesics and the administration of adjuvant drugs. ${ }^{2}$

K Liukkonen et al. Reported a $16 \%$ incidence of nausea and vomiting with Tramadol administration in 75 subjects out of 156 populations in the postoperative arthroscopy study. ${ }^{3}$ Lee et al. Compared the incidence of vomiting on intravenous administration of tramadol in combination with oral paracetamol with ketorolac in combination with oral paracetamol in trauma-induced muscle pain, in which the incidence of nausea and vomiting was higher in the group receiving Tramadol. ${ }^{4}$ 
Vol 6 No 1 February 2021

BULTIN

FARMATERA

E-ISSN: 2528-410X

Zamiri et al. Compared ibuprofen, celecoxib, and oral tramadol after Graham tooth extraction and found a 58\% incidence of nausea and vomiting in the Tramadol group. ${ }^{5}$ This study aims to compare the incidence of nausea and vomiting after administration of tramadol $100 \mathrm{mg}$ suppository intravenously in lower limb surgery patients who received spinal anesthesia.

\section{METHODS}

This study was a double-blind randomized experimental study, involving 36 research subjects at the $H$. Adam Malik General Hospital Medan and the Network Hospital in June - October 2013 who underwent lower limb surgery with spinal anesthesia using Bupivacaine $0.5 \%$ hyperbaric $20 \mathrm{mg}$. . The research subjects were divided into 2 groups, 18 subjects each, group A received $100 \mathrm{mg}$ tramadol suppository and intravenous placebo and group B received $100 \mathrm{mg}$ intravenous tramadol and placebo suppository. Subjects were evaluated for 24 hours postoperatively, starting from 1,6,12 and 24 hours, recorded the incidence of nausea and vomiting, and conducted hypothesis testing between the two treatment groups with paired T test. ${ }^{6}$

\section{RESULTS \\ 4.1 Types of surgery}

Table 1. Distribution of surgical procedures types

\begin{tabular}{|c|c|c|c|}
\hline \multirow{2}{*}{$\begin{array}{l}\text { Types of surgical } \\
\text { procedures }\end{array}$} & \multicolumn{2}{|c|}{ Groups } & \multirow[t]{2}{*}{ Total } \\
\hline & A & $B$ & \\
\hline Debridement & $1(5,6 \%)$ & $(0 \%)$ & $1(2,8 \%)$ \\
\hline Excision & $2(11,1 \%)$ & $(0 \%)$ & $2(5,5 \%)$ \\
\hline Abscess incision & $(0 \%)$ & $1(5,6 \%)$ & $1(2,8 \%)$ \\
\hline Incisional biopsy & $(0 \%)$ & $1(5,6 \%)$ & $1(2,8 \%)$ \\
\hline OREF femur & $1(5,6 \%)$ & $(0 \%)$ & $1(2,8 \%)$ \\
\hline OREF tibia & $2(11,1 \%)$ & $2(11,1 \%)$ & $4(11,1 \%)$ \\
\hline ORIF & $1(5,6 \%)$ & $(0 \%)$ & $1(2,8 \%)$ \\
\hline ORIF Ankle & $(0 \%)$ & $1(5,6 \%)$ & $1(2,8 \%)$ \\
\hline ORIF Femur & $2(11,1 \%)$ & $5(27,8 \%)$ & $7(19,4 \%)$ \\
\hline ORIF tibia & $1(5,6 \%)$ & $1(5,6 \%)$ & $2(5,5 \%)$ \\
\hline $\begin{array}{l}\text { Release+skeletal } \\
\text { traction }\end{array}$ & $3(16,7 \%)$ & $1(5,6 \%)$ & $4(11,1 \%)$ \\
\hline Removal Implant & $4(22,2 \%)$ & $2(11,1 \%)$ & $6(16,7 \%)$ \\
\hline Skeletal traction & $1(5,6 \%)$ & $1(5,6 \%)$ & $2(5,5 \%)$ \\
\hline STSG & $(0 \%)$ & $3(16,7 \%)$ & $3(8,3 \%)$ \\
\hline Total & $18(100 \%)$ & $18(100 \%)$ & $36(100 \%)$ \\
\hline
\end{tabular}

Nausea at the first hour in group A was $5.6 \%$ and group B was $66.7 \%$ with a value of $p=0.000$ meaning that there was a significant difference. Nausea at the 6th hour in group A was $16.7 \%$ and in group, B was $5.6 \%$ with a $\mathrm{p}$-value $=0.289$ meaning there was no significant difference.

Table 2. Distribution of Nausea

\begin{tabular}{|c|c|c|c|c|c|}
\hline \multirow[t]{3}{*}{ Duration } & \multicolumn{4}{|c|}{ Groups } & \multirow[t]{3}{*}{$\mathbf{P}$} \\
\hline & \multicolumn{2}{|c|}{$A$} & \multicolumn{2}{|c|}{ B } & \\
\hline & Positive & Negative & Positive & Negative & \\
\hline 1 st hour & $1(5,6 \%)$ & $17(94,4 \%)$ & $12(66,7 \%)$ & $6(33,3 \%)$ & 0,000 \\
\hline $6^{\text {th }}$ hours & $3(16,7 \%)$ & $15(83,3 \%)$ & $1(5,6 \%)$ & $17(94,4 \%)$ & 0,289 \\
\hline $12^{\text {th }}$ hours & $2(11,1 \%)$ & $16(88,9 \%)$ & $8(44,4 \%)$ & $10(55,6 \%)$ & 0,026 \\
\hline $24^{\text {th }}$ hours & $1(5,6 \%)$ & $17(94,4 \%)$ & $2(11,1 \%)$ & $16(88,9 \%)$ & 0,546 \\
\hline Total & 7 & & 23 & & \\
\hline
\end{tabular}


Vol 6 No 1 February 2021

Table 3 Distribution of Vomiting

\begin{tabular}{|c|c|c|c|c|c|}
\hline \multirow{3}{*}{ Duration } & \multicolumn{4}{|c|}{ Group } & \multirow{3}{*}{$P$} \\
\hline & \multicolumn{2}{|c|}{ A } & \multicolumn{2}{|c|}{ B } & \\
\hline & positive & Negative & Positive & Negative & \\
\hline $1^{\text {st }}$ hour & $(0 \%)$ & $18(100 \%)$ & $3(16,7 \%)$ & $15(83,3 \%)$ & 0,070 \\
\hline $6^{\text {th h hours }}$ & $2(11,1 \%)$ & $16(88,9 \%)$ & $1(5,6 \%)$ & $17(94,4 \%)$ & 0,546 \\
\hline $12^{\text {th }}$ hours & $1(5,6 \%)$ & $17(94,4 \%)$ & $6(33,3 \%)$ & $12(66,7 \%)$ & 0,035 \\
\hline $24^{\text {th }}$ hours & $(0 \%)$ & $18(100 \%)$ & $(0 \%)$ & $18(100 \%)$ & \\
\hline Total & 3 & & 10 & & \\
\hline
\end{tabular}

Nausea on the 12th hour in group A was $11.1 \%$ and in group B was $44.4 \%$ with a p-value $=0.026$, meaning that there was a significant difference. Nausea at 24 hours in group A was 5.6\% and in the group, B was $11.1 \%$ with a $\mathrm{p}$-value $=0.546$ meaning there was no significant difference.

Vomiting at the first hour in group A was $0 \%$ and in the group, B was $16.7 \%$ with a $\mathrm{p}$-value $=0.070$ meaning there was no significant difference. Vomiting at the 6th hour in group A was $11.1 \%$ and in the group $B$ was $5.6 \%$ with a value of $p=0.546$ meaning there was no significant difference. Vomiting at 12 hours in group A was $5.6 \%$ and in group B was $33.3 \%$ with a value of $p$ $=0.035$, meaning that there was a significant difference.

\section{DISCUSSION}

From the results of the study, it is very clear that the incidence of PONV is lower in the group that received Tramadol suppositories, this is strongly suspected because the difference in the rate of drug absorption by suppositories to achieve systemic blood circulation is much slower than intravenous administration, this is because the rectum is the final part of the system. The intestinal has a much lower absorption function compared to the small intestine, besides that drug administration through the intestinal tract also undergoes the first-pass metabolism in the liver which results in much less bioavailability of the drug in the circulation when compared to intravenous administration. The low bioavailability of drugs results in a low amount of free drugs in the blood circulation, which in turn results in much less drug concentration on the surface of the receptors so that the possibility to bind to analog receptors in other tissues is much less so than the drug administration effect is also much smaller than that by giving intravenously. ${ }^{2}$

One of the mechanisms for vomiting is due to stimulation at the Chemoreceptor Trigger Zone (CTZ) in posttrauma which stimulates the vomiting center in the medulla. Chemoreceptors that can be found on CTZ are 5-HT3, dopamine type 2 (D2), opioids, and neurokinin-1 (NK-1). Tramadol is a $\mu$-opioid receptor-selective agonist and inhibits serotonin (5-HT) reuptake. Whereas (-) - tramadol mainly inhibits noradrenaline (NA) reuptake, stimulates $\alpha 2$-adrenergic receptors but has little affinity for $\mu$-opioid receptors. ${ }^{7,8}$ Based on this theory, if we relate it to the drug administration mechanism given, it is clear that the 
administration of tramadol suppositories will prolong absorption and increase drug degradation compared to intravenous administration of tramadol, this will also lead to less drug bioavailability in blood plasma. and the time to reach peak drug levels is much longer on suppositories, what then happens is that the 5HT3 reuptake inhibition is also less and slower so that the stimulation of 5HT3 chemoreceptors in CTZ is also much less. ${ }^{9}$

Linz in 1998 conducted a crossover study of 10 subjects who were given a single dose of $100 \mathrm{mg}$ of tramadol HCL and 100 $\mathrm{mg}$ in $2 \mathrm{~mL}$ of injection solution where previously a washout procedure was carried out for 1 week to get the result that the maximum serum level in suppository administration was achieved within 2 -6 hours post-administration, with a bioavailability ratio of $2933+/-304 \mathrm{~h} . \mathrm{ng} / \mathrm{ml}$ (suppositories) and $3775+/-446$ h.ng/ml (iv).

From the results of the study, it can be seen that the lower bioavailability in intravenous administration causes the drug concentration at the receptor surface to be less than intravenous so that the possibility of stimulation of the vomiting center by CTZ as a result of high circulating serotonin concentrations is lower on suppository administration. ${ }^{10}$

In addition, to differences in the bioavailability of tramadol in plasma, suppositories can also reduce the irritation of the gastrointestinal surface by the acidic tramadol, this can prevent the stimulation of the vagus nerve which is also involved in the occurrence of nausea and vomiting. ${ }^{11,12,13}$

Differences in the pharmacokinetics of giving tramadol suppositories have also been investigated by Zwaveling $\mathrm{J}$ et al in 2004, in this study it appears that the administration of rectal tramadol suppositories is well absorbed and shows a relatively low absorption and clearance process when compared to oral or intravenous administration. ${ }^{14}$

\section{CONCLUSION}

Administration of Tramadol suppositories causes less nausea and vomiting than intravenous tramadol.

\section{REFERENCES}

1. Apfrel CC, Stoecklein K, Lipfert P. Pony a problem of inhalation anesthesia. Anesthesia. 2005;19(3):485-500.

2. Setiawati A, Suryatna FD GA. Pengantar Farmakologi, in: Farmakologi Dan Terapeutik Fakultas Kedokteran Universitas Indonesia. 6th ed. Badan Penerbit FK UI; 2016.

3. Liukkonen K, Santanen U,Pere P, Erkola O, Rautoma P. Peroral tramadol premedication increases postoperative nausea and delay homereadiness in day-case knee arthroscopy patients. Scand J Surg. 2002;91(2):365-368.

4. Lee HKH, Ting SM, Lau FL. A randomized control trial comparing the efficacy of tramadol and paracetamol agoints ketorolac and

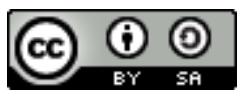


paracetamol in the management of musculoskletal pain in the emergency departement hongkong. J Emerg Med. 2008;15(2):5-11.

5. Zamiri B, Mousavizadeh K, Tajoddini M, Mohammadinezhad C, Aarabi AM. Comparison of ibuprofen, celecoxib and tramadol in relief of pain after extraction of mandibular third molar theeth. Iran Red Crescent Med J. 2009;11(4):431-436.

6. MS D. Statistik Untuk Kedokteran. 5th ed. Salemba Medika; 2008.

7. EA S. Tramadol present and future, anaest. Intensive Care J. 2000;28(3):363-374.

8. Putra HBA, Subarnas A. Penggunaan klinis tramadol dengan berbagai aspek. Farmaka. 2019;17(2):244-249.

9. Grond S, Sablotzki A. Clinical pharmacology of tramadol. In: Clinical Pharmacokinetic. ; 2012:879-823.

10. Lintz W, Barth H, Osterloh G, Schmidt BE. Pharmacokinetic of tramadol and bioavailability of enternal tramadol formulation $3 \mathrm{rd}$ communication suppositories. In: ; 1998:889.

11. Saleem MA, Taher M, Sanaullah S, Najmuddin $\mathrm{M}$, Ali $\mathrm{J}$, et all. Formulation and evaluation of tramadol hydrochloride rectal suppositories. Indian $\mathrm{J}$ Pharm Sci. 2008;70(50):640-644.

12. Rahman MH, Beattie J. Post-operative nausea and vomiting. Pharm J. 2004;273(2):786-788.
13. Ho KY, Chiu JW. Multimodal antiemetic therapy and emetic risk profiling. In: Ann Acad Med Singapore. ; 2005:196-205.

14. Zwaveling J, Bubbers S, Van Meurs AHJ, Schoemaker. Pharmacokinetics of rectal tramadol in postoperative pediatric patients. J Anaesth. 2004;93(2):224-227. 